Scientific Review - Engineering and Environmental Sciences (2020), 29 (2), 212-222

Sci. Rev. Eng. Env. Sci. (2020), 29 (2)

Przegląd Naukowy - Inżynieria i Kształtowanie Środowiska (2020), 29 (2), 212-222

Prz. Nauk. Inż. Kszt. Środ. (2020), 29 (2)

http://iks.pn.sggw.pl and Environment

DOI 10.22630/PNIKS.2020.29.2.18

Zahraa M. HASSAN ${ }^{1,2}$, Monim H. Al-JIBOORI ${ }^{2}$, Hazima M. Al-ABASSI ${ }^{3}$

${ }^{1}$ Iraqi Ministry of Health and Environment

${ }^{2}$ Mustansiriyah University, College of Science

${ }^{3}$ University of Baghdad, Ibn al-Haytham College of Education

\title{
Heat waves and health impact on human in Baghdad
}

Key words: heat wave, max air temperature, CBC analysis, Baghdad

\section{Introduction}

Global climate change would affect human health via pathways of varying complexity, scale and directness and with different timing. Similarly, impacts would vary geographically as a function both of environment and topography and of the vulnerability of the local population (Michael, 2007; Mogil, 2007). Impacts would be both positive and negative (although expert scientific reviews anticipate predominantly negative). This is no surprise since climatic change would disrupt or otherwise alter a large range of natural ecological and physical systems that are an integral part of Earth's life support system (NWS-NOAA, 2014). Via climate change humans are contributing to a change in the conditions of life on earth. The main pathways and catego- ries of health impact of climate change are shown in Figure 1.

The more direct impacts on health include those due to changes in exposure to weather extremes (heat waves, winter cold); decreases in winter mortality due to milder winters may compensate for increases in summer mortality due to the increased frequency of heat waves (Sessler, 2009). In countries with a high level of excess winter mortality, such as the United Kingdom (Langford \& Bentham, 1995; Roony, McMichael, Kovats \& Coleman, 1998). The health impacts of climate variability are, in general, likely to be more pronounced over the near term than are those of climate change. For example, large anomalies in temperature and rainfall in a particular season could cause a number of vector-borne and water-borne epidemics, thereafter the weather could return to normal. Extremes of heat can cause heat exhaustion, cardiovascular disease (heart attacks and 


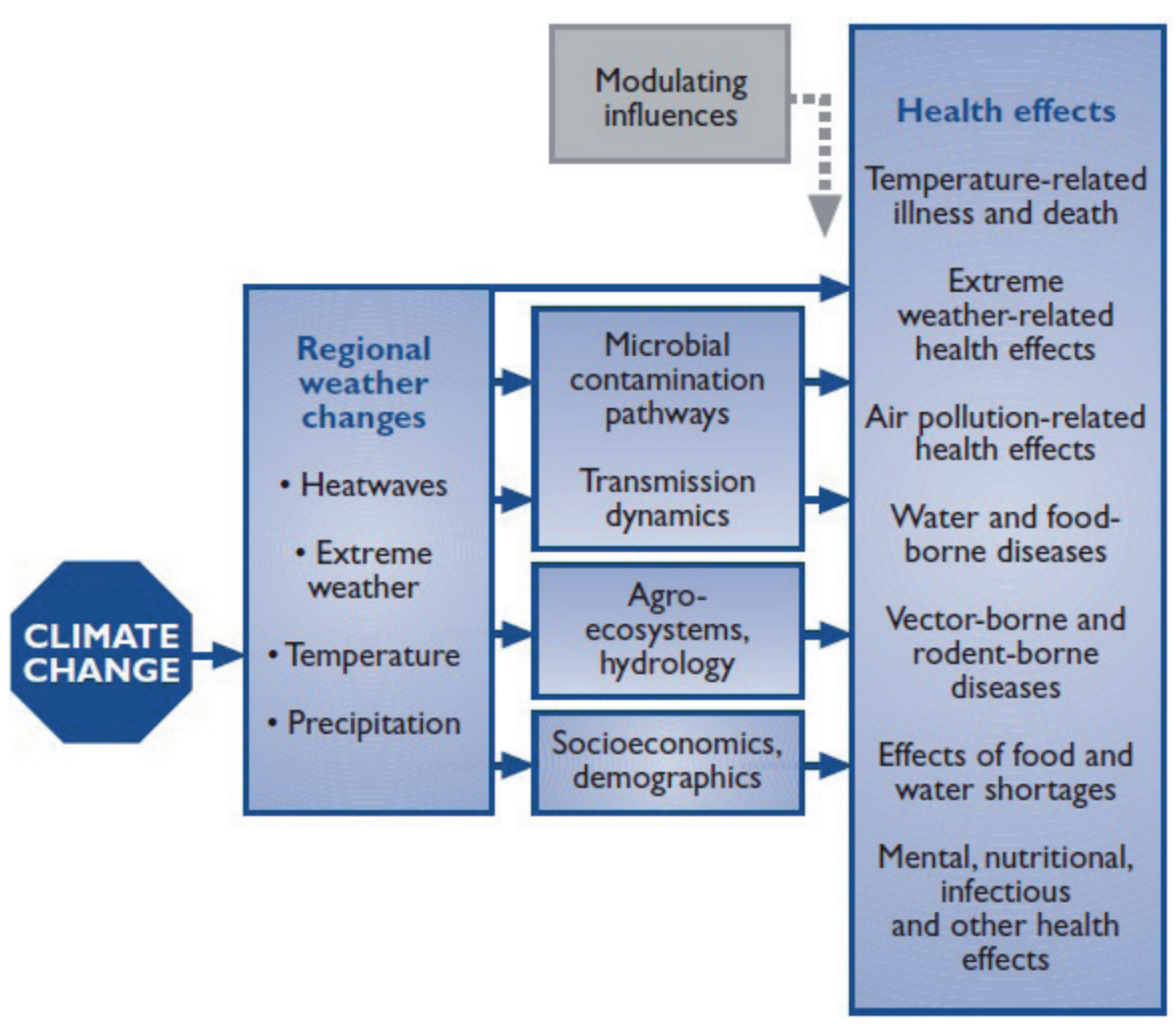

FIGURE 1. Pathways by which climate change affects human health, including local modulating influences and the feedback influence of adaptation measures (Patz et al., 2000)

strokes) while cold spells can lead to hypothermia and increase morbidity and mortality from cardiovascular disease (Lindsay \& Martens, 2000).

In this research, 40 blood samples were taken from the individual exposure heat wave and the necessary laboratory tests were performed. Most of the tests were conducted by specialized doctors, where these readings were taken from the laboratories of hospitals (medical city), Ibn al-Baladi Children's Hospital, Kadhimiya and Sheikh Zayed hospital by age groups (10-60 years) and for both genders. This study is the first study of its kind in the Department of Atmospheric Sciences, but for laboratory tests, it gives basic and basic laboratory indicators to monitor human health and reveals the presence of disorders in the vital functions of the human body; these tests include: ESR, CRP, HB, PL, PCV.

Erythrocyte sedimentation rate (ESR) is a blood sedimentation test, which is a laboratory test, in which the blood components are deposited and calculates the time taken for sedimentation. Level of erythrocyte sedimentation for inflammation in the body. Infections generally cause the proteins in the blood cells to change, causing them to bind in mass, becoming denser than proteins in normal blood cells. The ESR test simply measures the rate of deposition in the 
cells. The lower the test tube, the faster it falls down, the more inflammatory it is in the body (Michael, 2015). Table 1 presents normal values according to the Westergren method.

TABLE 1. The Westergren method standards for ESR according to age and sex

\begin{tabular}{|l|c|}
\hline Specification & $\begin{array}{c}\text { Normal value } \\
{\left[\mathrm{mm} \cdot \mathrm{h}^{-1}\right]}\end{array}$ \\
\hline Newborn & $0-2$ \\
\hline Children & $1-10$ \\
\hline Males in total & $0-25$ \\
\hline aged 0-50 & $<15$ \\
\hline aged 51-85 & $<20$ \\
\hline aged $>85$ & $<30$ \\
\hline Females in total & $0-30$ \\
\hline aged 0-50 & $<20$ \\
\hline aged 51-85 & $<30$ \\
\hline aged $>85$ & $<42$ \\
\hline
\end{tabular}

C-reactive protein (CRP) is an analysis done to determine the amount of protein in the blood in the human body and is an abbreviation of the medical term $\mathrm{C}$-reactive protein. If this protein is found to increase in blood, it means that the person has acute inflammation, which helps the doctor to diagnose and treat some diseases (Chen et al., 2006). There are two types of CRP test: (1) regular CRP: protein test found in very high blood between 10 and 1,000. This test is used to determine the presence of inflammation or infection in the body; (2) high sensitivity CRP: high-sensitivity protein test, which helps in measuring the proportion of light color protein in the blood between 0.05 and $10 \mathrm{mg} \cdot \mathrm{l}^{-1}$. It is used in normal people to determine the extent of coronary insufficiency or some heart disease.

Hemoglobin (HB) analysis is useful to know the patient's blood status in case of anemia (anemia, bleeding, infection or allergy), depending on the height of each component of the blood or low.

Platelet counts (PL) are part of the $\mathrm{CBC}$ analysis to determine the triglycerides and the standard and percentage of each.

Packed cell volume (PCV) is one of the $\mathrm{CBC}$ tests, which is the ratio of the size used by red blood cells, and is a way to determine whether the number of red blood cells is high or low or normal.

TABLE 2. Reference values unit normal the Westergren $\mathrm{CBC}$ value range for male and female

\begin{tabular}{|l|c|}
\hline Factor & Value \\
\hline WBC & $5.00 \cdot 10^{3} \mathrm{iu}$ \\
\hline HB & $11.0-14.0 \mathrm{~g} \cdot \mathrm{dl}^{-1}$ \\
\hline PCV & $11.6-14.0$ \\
\hline PL & $150 \cdot 10^{3} \mathrm{iu}$ \\
\hline
\end{tabular}

\section{Climate of Baghdad}

Baghdad is the capital of Republic of Iraq and is located in the middle of it along the Tigris river. It splits Baghdad in half, with the eastern half being called Risafa and the western half known as Karkh (Fig. 2). Geographically, Baghdad is situated at latitude $33.6-33.5^{\circ} \mathrm{N}$, longitude $44.25-44.5^{\circ} \mathrm{E}$ and $30-38 \mathrm{~m}$ above mean sea level (msl). It covers an area of $857.3 \mathrm{~km}^{2}$ and forms $0.2 \%$ of an overall Iraq area and is in the heart 


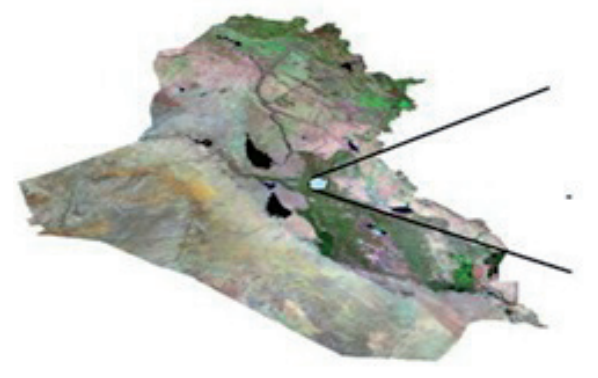

of ancient Mesopotamia. The land is almost entirely flat and low-lying. The climate of Baghdad has a subtropical desert climate (Köppen climate classification $\mathrm{BWH}$ ) featuring extremely hot, dry summer and mild, damp winter (Roth, 2007). The mean annual range of air temperature over a whole gear is $15-34^{\circ} \mathrm{C}$ with the mean of $25^{\circ} \mathrm{C}$, while annual range of the mean daily sunshine duration is about 10-14-14 h with mean of $7.5 \mathrm{~h}$.

\section{Material and methods}

\section{Study group}

The study was conducted for the period of June, July and August 2019, it included 40 blood samples for patients exposed to heat waves who attended to

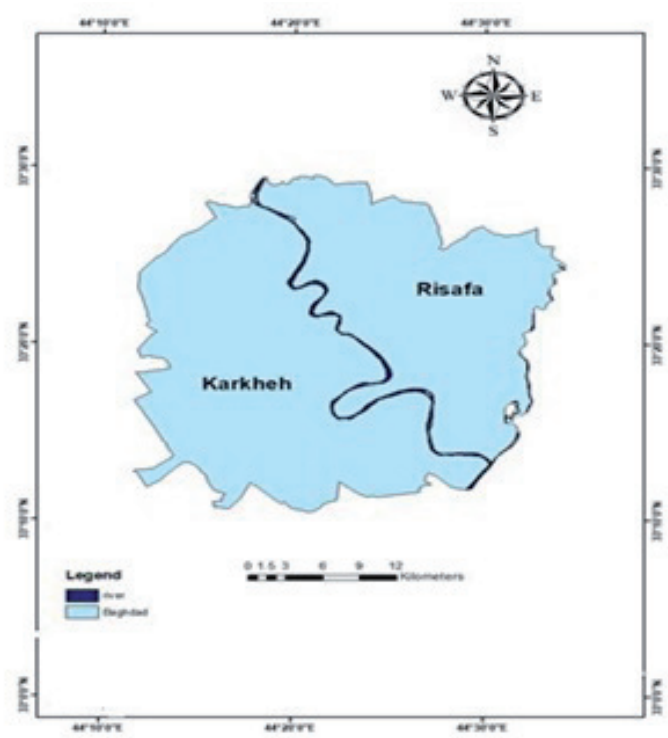

Medical City, Ibn Al-Baladi, Sheikh Zayed, Kadhimiya Educational with male and female ages 10-60 years, CBC analysis was performed.

\section{Blood sample}

Blood venous $(5 \mathrm{ml})$ was withdrawn from 40 patient's by using sterile medical syringe and placed in clean, dry plastic tubes free of anticoagulants and let it coagulate at room temperature and then placed in a centrifuged for $10 \mathrm{~min}(3,000$ rpm) to separate serum.

\section{Statistical analysis}

Statistical analysis of the data was carried out using (SigmaPlot) software to analyze the results and conclude the variance. The significant values of the analyses were calculated (CRP, ESR, 
WBC, PL, PCV). The mean values were calculated for each age group which divided in to five sub-groups, each group comprising (10 years) shown in Table 3, as well as calculated the deviation and percentage for each group.

TABLE 3. Number of patients exposed to heat wave

\begin{tabular}{|c|c|}
\hline $\begin{array}{c}\text { Age } \\
\text { group }\end{array}$ & $\begin{array}{c}\text { Numbers } \\
\text { of cases }\end{array}$ \\
\hline $10-19$ & 8 \\
\hline $20-29$ & 6 \\
\hline $30-39$ & 14 \\
\hline $40-49$ & 6 \\
\hline $50-60$ & 6 \\
\hline Total & 40 \\
\hline
\end{tabular}

\section{Result and discussion}

\section{Daily average of maximum air temperature}

The air temperature is one of the important atmospheric elements because of its wide effects on climate variables. Baghdad's climate was described using maximum temperatures in the summer. The monthly trend data for the three months of the summer (June, July and August) and the results showed that the general trend of temperature has increased over time clearly over the monthly averages despite the variation in these rates as shown in Table 4 . Where the average temperature for the month of June (42.72) was the standard deviation for it (3.314), the average temperature for July (47.53) and the standard deviation was (1.816), the average temperature for the month of August (47.4) and the standard deviation for it (2).
TABLE 4. Average and standard deviation for three summer months for the year 2019

\begin{tabular}{|c|c|c|}
\hline Month & $A V G$ & $S D$ \\
\hline June & 42.72 & 3.314 \\
\hline July & 47.53 & 1.816 \\
\hline August & 47.4 & 2 \\
\hline
\end{tabular}

Figure 3 shows the daily air max temperatures for the three summer months (June, July and August) for the year 2019, where we notice through these forms that the general trend of temperatures indicates an increase despite the presence of fluctuations ranging from increase and decrease, and that the summer months (June, July and August) are distinguished by the fact that it has an increasing trend of temperatures as shown in Figure 3.

As shown in Table 5 which illustrated the mean and percent value for CRP, ESR and CBC analyze for patients (male). Table 5 also shows the average temperature of three months of summer (June, July, August) for the year 2019.

The result for CRP was (mean and percent) for all age group (10-60 years) the mean were $(12,14.5,17,15.5,17)$ respectively and the percent were $(92 \%$, $99 \%, 100 \%, 100 \%, 100 \%)$ respectively we observe a highly percent was in age group (30-39, 40-49 and 50-60). This result was in a concordance with performed by (Chen et al., 2006).

CRP was elevated after exposure to infectious agent and consider as a biomarker for detecting of acute inflammation but there is no explanation for their elevation after exposing to heat wave because there is no previous studies focus in this field.

The result for ESR was (mean and percent) for all age group (10-60 years) 

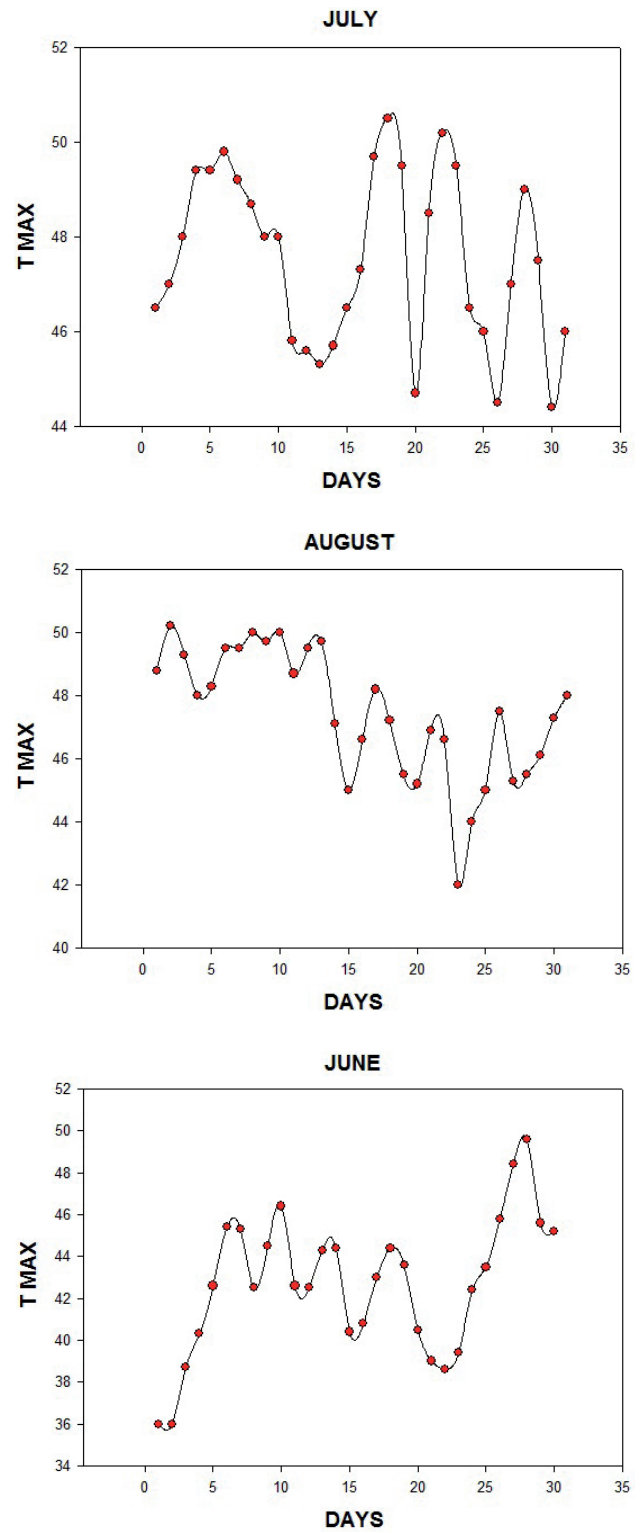

FIGURE 3. Daily air max temperature for three months (June, July and August) for 2019

the mean were $(43,40.5,53.5,43,49)$ respectively, the percent were $(99 \%$, $101 \%, 100 \%, 100 \%, 100 \%$ ) respectively, we observe a highly percent was in age groups (30-39 and 50-60). This result was in an agreement which performed by Michael (2015).

The increased rate of erythrocyte sedimentation is only an indication of inflammation or disease in the human body as it interacts with acute conditions in the body that lead to a rise in the level of ESR in the blood (MedlinePlus, 2012).

The result for $\mathrm{CBC}$ analyze (WBC, PCV, PL) (mean and percent) for all age groups (10-60 years) were WBC (10.5, $14.15,11.35,11.55,11)$ respectively $(99 \%, 101 \%, 100 \%, 100 \%, 99 \%)$ respectively we observe a highly percent was in age groups (20-29). PCV $(27,36$, $28,28.5,32)$ respectively $(100 \%, 100 \%$, $100 \%, 100 \%, 100 \%)$ respectively, we observe a highly percent in age groups (20-29, 50-60) and PL (215, 268.5, $182.5,215.5,215)$ respectively, $(101 \%$, $101 \%, 100 \%, 100 \%, 100 \%)$ respectively, we observe a highly percent in age groups (10-19, 20-29, 30-39, 40-49, 50-60). This result was in an agreement which performed by Reiser (1981) and Brewer (2006).

As shown in Table 6 which illustrated the mean and percent value for CRP, ESR and CBC analyze for patients (female). Table 6 also shows the average max air temperature of three months of summer (June, July, August) for the year 2019 which was (45.8). The result for CRP (mean and percent) for all age groups (10-60 years) were $(14,17,15$, $15,12)$ respectively $(99 \%, 100 \%, 100 \%$, $101 \%, 100 \%$ ) respectively, we observe a highly percents was in age groups 20-29, 30-39 and 40-49.

The result for ESR (mean and percent) for all age groups (10-60 years) were $46,31.5,43.5,47.5,31)$ respectively $(100 \%, 100 \%, 101 \%, 100 \%, 99 \%)$ re- 
TABLE 5. Result of CBC analyses for male for three summer months (June, July and August) for 2019

\begin{tabular}{|l|c|c|c|c|c|c|c|c|c|c|c|}
\hline Age & $\begin{array}{c}\text { Mean } \\
\text { CRP }\end{array}$ & CRP\% & $\begin{array}{c}\text { Mean } \\
\text { ESR }\end{array}$ & ESR\% & $\begin{array}{c}\text { Mean } \\
\text { WBC }\end{array}$ & WBC\% & $\begin{array}{c}\text { Mean } \\
\text { PCV }\end{array}$ & PCV\% & $\begin{array}{c}\text { Mean } \\
\text { PL }\end{array}$ & PL\% & $\begin{array}{c}T_{\max } \\
{\left[{ }^{\circ} \mathrm{C}\right]}\end{array}$ \\
\hline $10-19$ & 12 & 92 & 43 & 99 & 10.5 & 99 & 27 & 100 & 215 & 101 & \\
\hline $20-29$ & 14.5 & 99 & 40.5 & 101 & 14.15 & 101 & 36 & 100 & 268.5 & 101 \\
\hline $30-39$ & 17 & 100 & 53.5 & 100 & 11.35 & 100 & 28 & 100 & 182.5 & 100 & \multirow{2}{*}{45.8} \\
\hline $40-49$ & 15.5 & 100 & 43 & 100 & 11.55 & 100 & 28.5 & 100 & 215.5 & 100 \\
\hline $50-60$ & 17 & 100 & 49 & 100 & 11 & 99 & 32 & 100 & 215 & 100 \\
\hline Total & 15.5 & 100 & 43 & 100 & 11.35 & 100 & 28.5 & 100 & 215 & 100 & \\
\hline
\end{tabular}

TABLE 6. Result of CBC analyses for female for three summer months (June, July and August) for 2019

\begin{tabular}{|l|c|c|c|c|c|c|c|c|c|c|c|}
\hline Age & $\begin{array}{c}\text { Mean } \\
\text { CRP }\end{array}$ & CRP\% & $\begin{array}{c}\text { Mean } \\
\text { ESR }\end{array}$ & ESR\% & $\begin{array}{c}\text { Mean } \\
\text { WBC }\end{array}$ & WBC\% & $\begin{array}{c}\text { Mean } \\
\text { PCV }\end{array}$ & PCV\% & $\begin{array}{c}\text { Mean } \\
\text { PL }\end{array}$ & PL\% & $\begin{array}{c}T_{\max } \\
{\left[{ }^{\circ} \mathrm{C}\right]}\end{array}$ \\
\hline $10-19$ & 14 & 99 & 46 & 100 & 11.9 & 100 & 33 & 100 & 131 & 100 & \\
\hline $20-29$ & 17 & 100 & 31.5 & 100 & 10.85 & 100 & 30 & 100 & 220.5 & 100 & \\
\hline $30-39$ & 15 & 100 & 43.5 & 101 & 11.35 & 99 & 29 & 100 & 190.5 & 99 & \multirow{2}{*}{45.8} \\
\hline $40-49$ & 15 & 101 & 47.5 & 100 & 11.9 & 101 & 32.5 & 100 & 291 & 101 \\
\hline $50-60$ & 12 & 100 & 31 & 99 & 7.6 & 101 & 31 & 100 & 245 & 100 \\
\hline Total & 15 & 100 & 43.5 & 100 & 11.35 & 100 & 31 & 100 & 220.5 & 100 & \\
\hline
\end{tabular}

spectively, we observe a highly percents was in age groups (10-19, 30-39, 30-39 and 40-49).

The result for $\mathrm{CBC}$ analyze (WBC, $\mathrm{PCV}, \mathrm{PL})$ (mean and percent) for all age groups $(10-60$ years) were WBC $(11.9,10.85,11.35,11.9,7.6)$ respectively $(100 \%, 100 \%, 99 \%, 101 \%, 101 \%$, 99\%) respectively, we observe a highly percents in age groups $(10-19,20-29$, 30-39, 40-49). PCV $(33,30,29,32.5$, 31) respectively, $(100 \%, 100 \%, 100 \%$, $100 \%, 100 \%$ ) respectively, we observe a highly percent in age groups (10-19, 20-29, 30-39, 40-49, 50-60) and PL $(131,220.5,190.5,291,245)$ respectively $(100 \%, 100 \%, 99 \%, 101 \%, 100 \%)$ respectively, we observe a highly percents in age groups $(20-29,30-39,40-49$, 50-60).

Figures 4 and 5 show the number of high levels of $\mathrm{CBC}$ values for all age groups from (10-60 years) this rise appears clear in males more than females and due to the increase in diseases in males more than females due to the fact that the immune factor in men is lower than the immune factor in women because of the high estrogen in women which strengthens the immune system (MedlinePlus, 2012).

This study showed that platelets have a high count. The platelets that control levels of liquidity and blood clotting, if the medical results of more than 100,000 plates, this indicates a defect in 

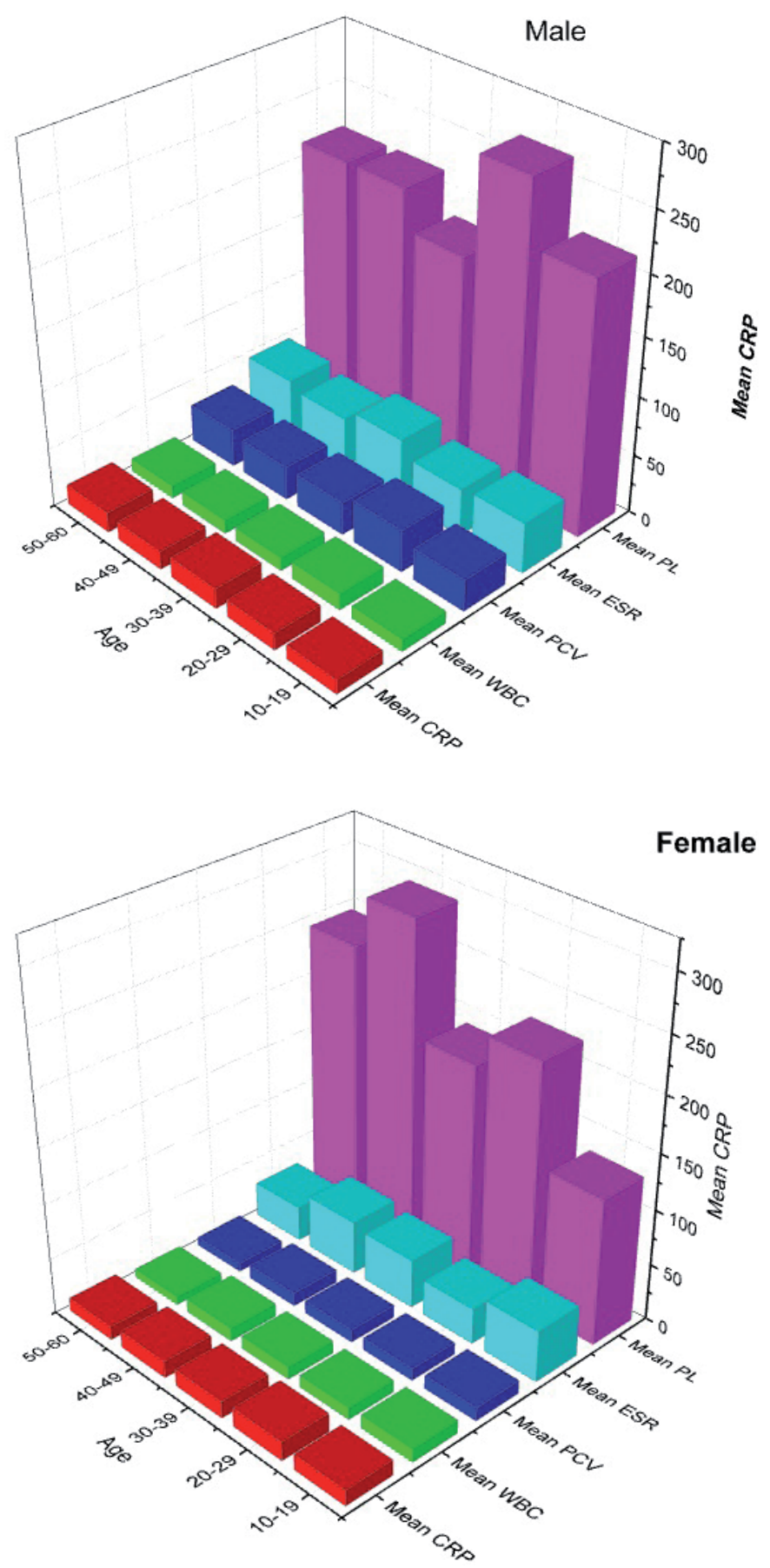

FIGURE 4. The mean of males and females exposed to heat waves for the period of June, July and August 2019 

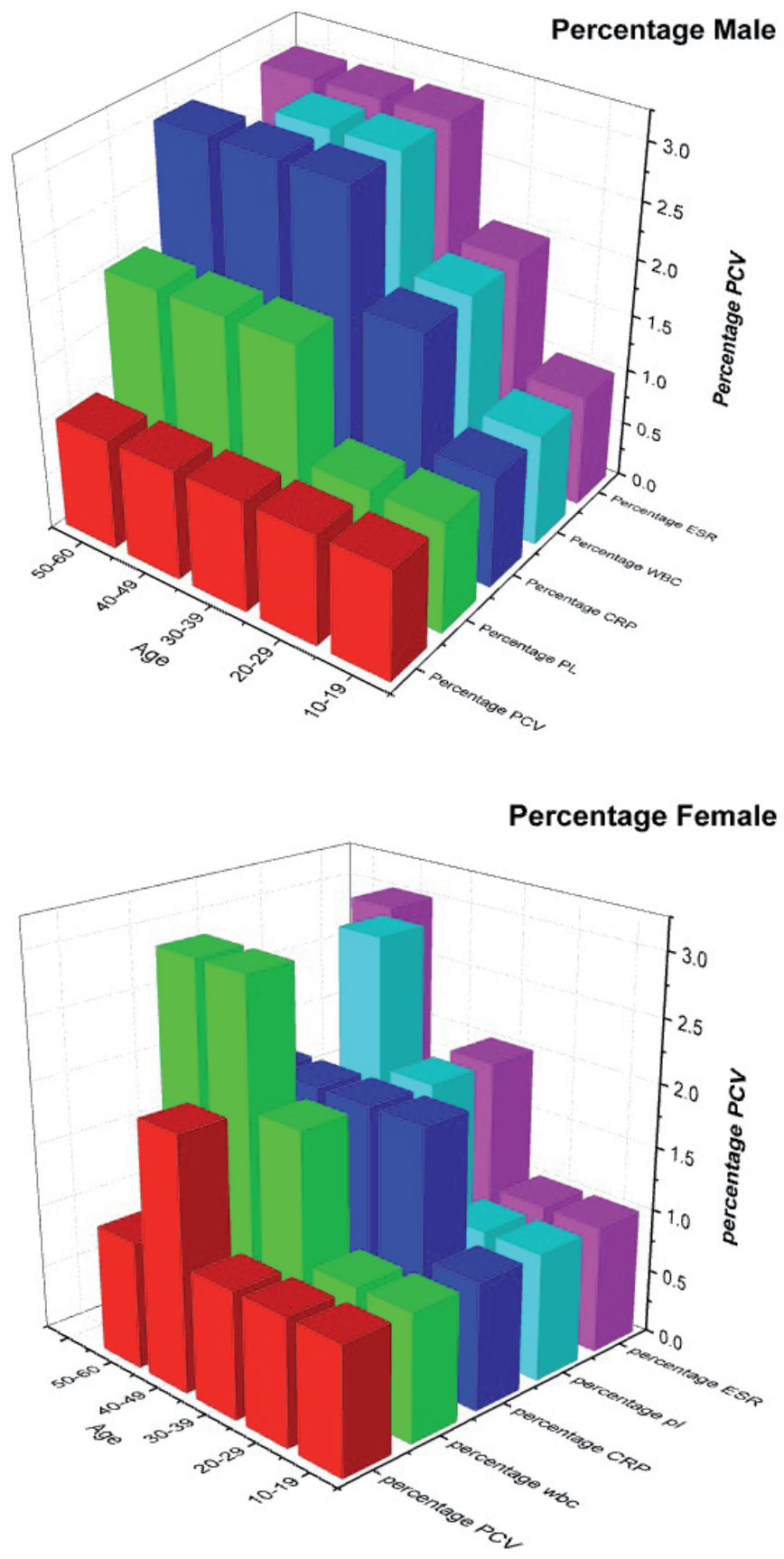

FIGURE 5. The percent of males and females exposed to heat waves for the period of June, July and August 2019 
blood fluid and this explains the injury of patients exposed to heat waves of heart clots and angina.

Hyperthermia is distinct from a fever heat stroke generally present with a hyperthermia of greater than $40.6^{\circ} \mathrm{C}$, combination with disorientation before when body exposure to high temperature and heat stroke keratinocytes can produces (IL-1) which interleukin induce hypothalamus to produce prostaglandin $\left(\mathrm{PGE}_{2}\right)$ with through interaction with the $\left(\mathrm{GP}_{3}\right)$ receptor stimulates neurotransmitters such as cyclic adenosine monophosphate and increase body temperature.

Also this cytokines stimulate production of inducible cycloxygenase (arachidonic acid metabolite) and through this pathway thromboxane $\mathrm{A}_{2}\left(\mathrm{TXA}_{2}\right)$ will produce which causes vasoconstriction and promote platelet aggregation, as a consequence dissemination clotted will occur and multiorgan failure is the main cause of death.

\section{Conclusion}

According to the result of present study we can conclude that all people who exposed for heat wave are under risk to initiate heart attack that may occur due to the highly significant increasing in their platelet count and CRP level.

\section{References}

Brewer, D.B. (2006). Max Schultze (1865), G. Bizzozero (1882) and the discovery of the platelet. British Journal of Haematology, 133(3), 251-58.

Chen, C.M., Hou, C.C., Cheng, K.C., Tian, R.L., Chang, C.P. \& Lin, M.T. (2006). Activated protein $\mathrm{C}$ therapy in a rat heat stroke model. Critical Care Medicine, 34(7), 1960-1966.

Langford, I.H. \& Bentham, G. (1995). The potential effects of climate change on winter mortality in England and Wales. International Journal of Biometeorology, 38(3), 141-147.

Lindsay, S. \& Martens, W.J.M. (1998). Malaria in the African Highlands: past, present and future. Bulletin of the World Health Organization, 76(1), 33-45.

Michael, H. (2015). Erythrocyte sedimentation rate and C-reactive protein. Australian Prescriber, 38(3), 93-94.

Mogil, H.M. (2007). Extreme weather. New York: Black Dog \& Leventhal Publishers.

National Weather Service - National Oceanic and Atmospheric Administration [NWS-NOAA] (2014-06-16). Heat: a major killer. Retrieved from: https:/www.weather.gov/grb/heat

Patz, J., McGeehin, M.A., Bernard, S.M., Ebi, K.L., Epstein, P.R., Grambsch, A., Gubler, D.J., Reither, P., Romieu, I., Rose, J.B., Samet J.M. \& Trtanj, J. (2000). The potential health impacts of climate variability and change for the United States: executive summary of the report of the health sector of the US National Assessment. Environmental Health Perspectives, 108(4), 367-376.

Reiser, S.J. (1981). Medicine and the reign of technology. Cambridge: Cambridge University Press.

Rooney, C., McMichael, A.J., Kovats, R.S. \& Coleman, M.P. (1998). Excess mortality in England and Wales, and in Greater London, during the 1995 heatwave. Journal of Epidemiology \& Community Health, 52(8), 482-486.

Roth, M. (2007). Review of urban climate research in (sub) tropical regions. International Journal of Climatology: A Journal of the Royal Meteorological Society, 27(14), 1859-1873.

MedlinePlus (2014-08-14). Medical Encyclopedia - ESR. Retrieved from: http://www.nlm. nih.gov/medlineplus/ency/article/003638. htm [access 14.08.2014].

Sessler, D. (2009). Thermoregulatory defense mechanisms. Critical Care Medicine, 37(7), 203-210.

World Meteorological Organisation [WMO] (2016). Provisional WMO statement on the status of the global climate in 2016. Retrieved 
from: https://public.wmo.int/en/media/pressrelease/provisional-wmo-statement-statusof-global-climate-2016

\section{Summary}

Heat waves and health impact on human in Baghdad. This investigation aim to evaluate the effect of heat wave on health of human, so to achieve this 40 blood samples for person exposed to heat wave were drawn most patients were attend to specialists in hospital laboratories (Medical City, Ibn al-Baladi, Sheikh Zayed, Kadhimiya Educational). The patients aged $10-60$ years, male (20) and female (20). CBC analyzes was performed. The result of the presents study recorded a highly significant difference in total (mean and percent) as compared with the normal value of the CBC analyze the result for total (mean and percent) for male the factors CRP, ESR, WBC, PCV, PL $(15.5,43$, $11.35,28.5,215)$ respectively $(100 \%, 100 \%$, $100 \%, 100 \%, 100 \%)$ and the result for total (mean and percent) for female the factors CRP, ESR, WBC, PCV, PL (15, 43.5, 11.35, $31,220.5)$ respectively $(100 \%, 100 \%, 100 \%$, $100 \%, 100 \%$ ). According to the result we can conclude that there was a highly significant deferent in mean value for patient compared with the normal value which is the mean cause of hard attack which lead to death. The study is the first of its kind in the Department of Atmospheric Sciences in Iraq.

\section{Authors' address:}

Zahraa M. Hassan

Ministry of Health, Bab-Al-Muadum, Baghdad, Iraq

22, 8 Baghdad

Iraq

e-mail: zahraamousa86@gmail.com 